\title{
Examining the Spatial Variability of Geosite Assessment and Its Relevance in Geosite Management
}

\author{
Márton Pál ${ }^{1}$ (i) • Gáspár Albert ${ }^{1}$ (D)
}

Received: 26 May 2020 / Accepted: 29 December 2020 / Published online: 23 January 2021

(C) The Author(s) 2021

\begin{abstract}
Assessment is the initial step for experts on geoheritage and geotourism when designating geosites in a certain area. During this process, geologically interesting outcrops, formations and places are examined with the use of different criteria to see if they are suitable for geoconservation and geotourism purposes. A quantitative assessment method-Modified Geosite Assessment Model (M-GAM) - was applied in the study area, which is part of the Bakony-Balaton UNESCO Global Geopark in Hungary. M-GAM uses a weight factor (importance) that expresses the opinion of geotourists about 27 infrastructural, tourism and scientific indicators. This factor was examined by questionnaires at nine geosites in the area. At each site, we determined a unique importance value, which shows significant difference from site-to-site and reflects the opinions of visitors about the geosite. The M-GAM method is originally aimed at applying a common weight on each of the 27 criteria during the assessment of selected sites. While this approach is valid, we demonstrated that the method can be extended because the weights spatially vary and can be used to draw conclusions on geosite management. Practically, the evaluation of the factors obtained in this way offers an individual development plan for every site. The current state of improvement direction, the level of communication and the interpretability of the geo-objects can also be determined. In this way, we can get a more realistic development strategy for the geosites.
\end{abstract}

Keywords Assessment $\cdot$ Geosite $\cdot$ Geopark $\cdot$ Balaton Uplands $\cdot$ Spatial

\section{Introduction}

Geotourism has multiple aims and purposes in the life of the community of an area. It presents geological objects as tourist attractions to the public and strengthens the identity of the local people. Its effect is notable on the area's economy as well as on job creation. As tourists without earth science background also visit these places, the sites should be well interpretable with the help of information boards, booklets or other kinds of infrastructure (Dowling 2011, Grant 2010). These places are called geosites (e.g., Brilha 2002; Joyce 2009). Geotourism has an important bond with geoheritage.

Márton Pál

marchello@map.elte.hu

Gáspár Albert

albert@ludens.elte.hu

1 Institute of Cartography and Geoinformatics, ELTE Eötvös Loránd University, Pázmány Péter sétány 1/A, Budapest 1117, Hungary
The spread of geosites is uneven on the Earth. There are places that have many geo-attractions, but some regions lack them - there are those kinds of objects that became tourist destinations, which would not stand out in geologically more varying regions. It is a difficult task to choose the sites that are worth presenting and need protection. Usually, experts who can determine the geoscientific, infrastructural and tourism value of a geosite do the assessment process. This explains why all infrastructure and tourism purposes stand on the basis of the scientific value of a geosite (Brilha 2016).

Quantitative models that include these three types of values are suitable to enhance the objectivity of the assessment and to make geosites comparable to each other (e.g., Reynard et al. 2007; Vujičić et al. 2011; Brilha 2016), while qualitative methods can pick those phenomena which are interesting in a geologically less diverse region or elements that are parts of a long-term strategy of establishing geoheritage promotion (Migoń 2018). There were several attempts to combine quantitative and qualitative methods to benefit from the numerical approach of the first one, and the recognition of local importance of the second one (e.g., Bruschi and Cendrero 2009; 
Pereira and Pereira 2010; Tomić and Božić 2014). Based on the outcomes of the evaluation, we can distinct those characteristics of a site that may generate geotourism. The result of an assessment refers to the actual state of the investigated sites whether it was created using quantitative or qualitative methods. Inventories of geosites need monitoring and reassessment from time to time due to anthropogenic or natural changes (e.g., infrastructural development, weathering and natural disasters), which can reduce or increase their geotourism potential (Brilha 2016). For example, the dinosaur footprints around Sintra, Portugal, are under massive erosion, while the newly built Paiva Walkways (near to Arouca, Portugal) experience higher visitor number owing to a significant infrastructural development (Brilha 2016).

If the geotourism potential of a geosite is high, it may become a subject of both tourism development and geoconservation. The assessment process has high responsibility, because only thorough and accurate evaluations may lead to appropriate results: just the truly important geosites should be under "geotourism protection". Such geositesdespite being frequented tourist attractions - can more successfully avoid harmful environmental impacts and investments compared to the unprotected ones (Leader European Observatory 1997).

In Hungary, the largest geopark with $3200 \mathrm{~km}^{2}$ area covering parts of the Balaton Uplands National Park and the High Bakony Protected Landscape was established in 2012 (Bakony-Balaton Geopark 2019). Other geoparks in the country were also founded around this time, and several individual geosites in the country were surveyed as potential tourist destinations (Horváth and Csüllög 2011; Horváth and Lóczy 2015; Szepesi et al. 2017). The assessment methods in these works were often based on the methodology of the quantitative GAM - Geosite Assessment Model (Vujičić et al. 2011). However, the establishment of the Bakony-Balaton UNESCO Global Geopark (BBG) was preceded only by qualitative evaluation (Korbély 2011). This is mainly because the areal extent of the BBG is large and geo-attractions are usually concentrated as clusters, which were considered as single geosites, despite each of these clusters contain several individual attractions. For example, the basalt volcanoes of the Tapolca Basin are parts of one single "volcanic landscape" geosite (Korbély 2011; Harangi 2014).

The BBG hosts one of the most visited tourist destinations in Hungary: Lake Balaton. Although most of the tourists do not choose geosites as their primary destinations, the geotourism potential is definitely present (e.g., one of the largest geo-attractions, Lóczy Cave is visited by approximately 35 000 tourists per year). Quantitative assessment of the BBG geosites in this frequented region would be an advantage when doing strategic planning for infrastructural developments. In 2017, a detailed assessment process was started by Pál et al. (2018) in the eastern part of the BBG using the
Modified Geosite Assessment Model (M-GAM) of Tomić and Božić (2014). The assessment's results identified the most attractive geosites in the examined area (Pál and Albert 2018).

M-GAM provided an opportunity for us to analyse the modificatory effect of the visitors' opinion on experts' evaluation. The model was derived from the GAM of Vujičić et al. (2011) to assess the geotourism potential of the Lazar Canyon area (Serbia). M-GAM differs from GAM by containing an Importance (Im) weight determined by interviewing geotourists at various geosites on their personal opinion of the importance of various indicators of the model. Then, the Im values were averaged to all geosites and used in the assessment as weights ranging between 0 and 1 for each indicator. The way M-GAM was applied by Tomić and Božić (2014) tells us which indicators are important for the visitors. However, by averaging the opinions, we lose information about the difference of these weights among the geosites.

When applying M-GAM in the assessment of the BBG geosites, our hypothesis was that the visitors' opinion of the criteria could give us a clue about their expectations concerning the geosites. Thus, the assessment of these sites does not only identify the most significant locations but also helps the geopark management to plan future infrastructural developments (Pál and Albert 2019).

Such assessment is useful for management purposes, and the site-specific opinion (the Im-s) of the visitors of each criterion is crucial for every geosite. We suspected that the averaged Im values would distort the assessment if doing sitespecific assessment as they do not explicitly represent the geosite that is under evaluation. Based on the results of the previous assessment, we have clustered the most visited natural attractions of the study area to further examine how the visitors weight the GAM indicators' importance. This study treats the Im value as a variable that can be effectively used separately at every examined geosite. The spatial variability of the geosite assessment in the present study is expressed in the site-specific evaluation of the collected data: the Im values change from geosite to geosite. Our aim was to examine how visitors see the actual scientific content and tourism facilities of the selected geosites by applying the M-GAM assessment method in a new way.

\section{Study Area: the Southeastern Part of the Bakony-Balaton UNESCO Global Geopark}

One of the most visited tourist destinations in Hungary and Central Europe is Lake Balaton and its surroundings. Visitors with various interests can entertain themselves in the area: there are beaches on the shore, famous wine cellars and rich cultural heritage. Due to the variety of natural (geological, biological) values, this area is even more characteristic. The 
northern shore of the lake is part of the Transdanubian Range and is well-known for its rare geological formations (Korbély 2011). The climate has Mediterranean nature near the shores, but on higher areas, it is temperately cool and wet. The mountains and hills do not make the formation of rivers possible, although there are small streams called "séd" in the deep valleys. The "séd" valleys have cool microclimate even during hot summer days (Dövényi 2012; Futó 2013).

An extensive geological mapping was done here in the 1990s and a 1:50 000 scale map was published in 1999 (Budai et al. 1999). The first geological hiking map of the area was published in 2018 (Albert et al. 2018). The rectangular shape of the examined territory (Fig. 1) covers the extent of the hiking map as well, because the editing work was done in parallel with the assessment. Until now, this $1: 30000$ map is the most detailed published geological map of the area.

The geological history dates back to the time when life was only present in seas. In the following half a billion years, volcanoes, deep and shallow seas, rivers crossing semi-deserts, tropical lagoons, lakes, streams and wind transformed the landscape. Today, humans are also remarkable surfacechanging factors (Albert et al. 2018). The oldest formations here are from the Silurian, which are more than 410 million years old. The Lovas Slate metasediment hides the small bodies of volcanic rocks called Alsóörs Metarhyolite. The outcrops and quarries of these formations are extremely rare

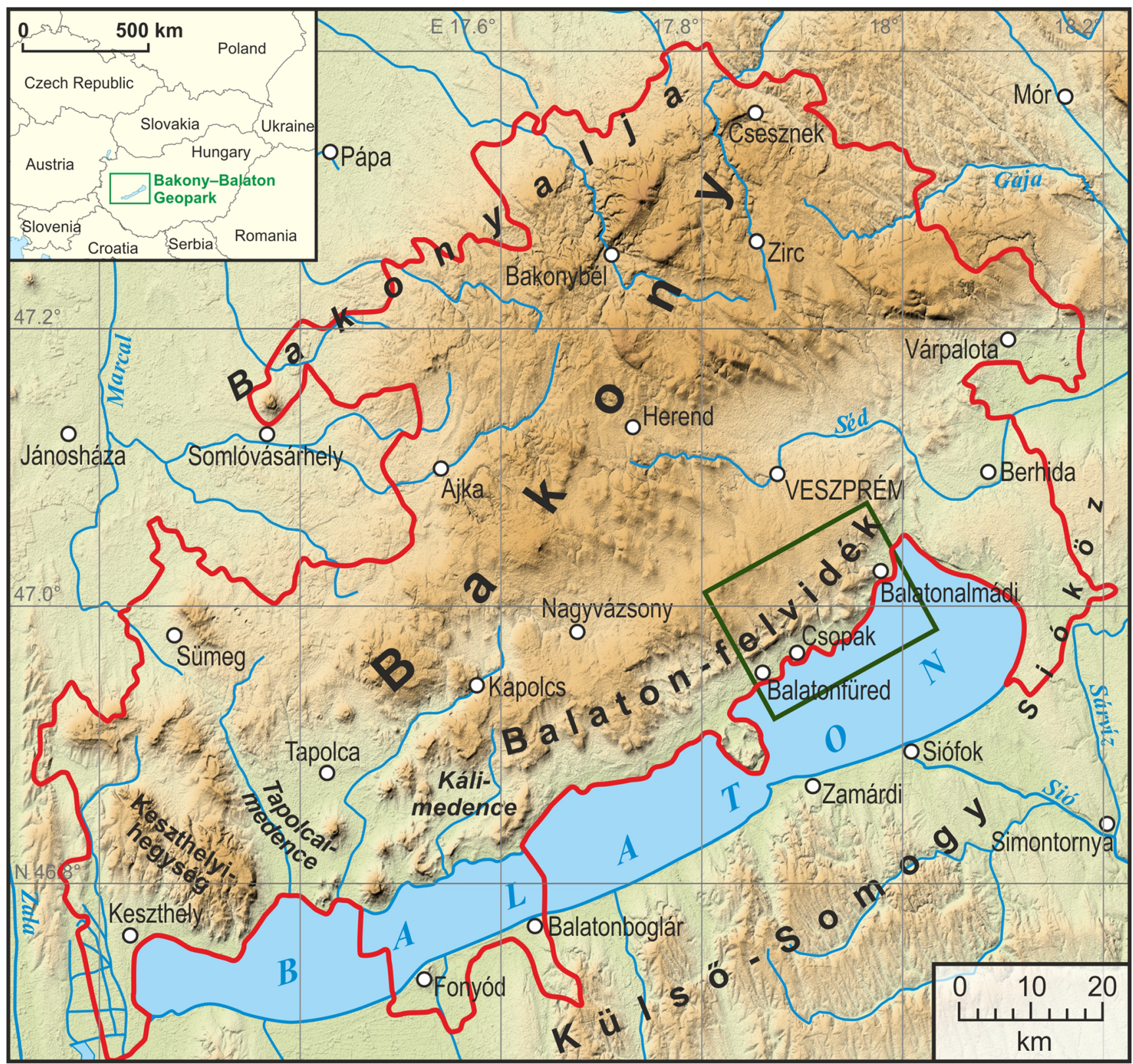

Fig. 1 The extent of the Bakony-Balaton Geopark (red border) and the examined area (green border) 
and highly protected due to geoconservation aims for the preservation of their visible scientific values. The metamorphism of these sedimentary rocks took place about 325-310 million years ago during the Variscan orogeny (Haas 2013).

A specific rock type of the area was formed during the Permian in fluvial and limnic environment: the red Balatonfelvidék (Balaton Uplands) Sandstone, which is commonly used as a building stone. A large part of the study area's outcrops is from the Mesozoic sedimentary sequence, which mainly consists of shallow-marine carbonates of Triassic age. The area tectonically belongs to the East Alpine Nappe System, so such rocks as in the Alps can be found here from this era referring to the large-scale tectonism that has shifted these formations to their current place (Haas 2013). The thickness of the Triassic carbonate sequence in the Bakony-Balaton region can reach $2.5-3 \mathrm{~km}$. Although Jurassic and Cretaceous sequences are not represented in the study area, they are found in the vicinity further to the north (Budai et al. 1999).

As the area was denuded during the Paleogene, only from the late Miocene can we find sediments next in connection with the development of the Pannonian Inland Sea (Korbély 2011). At this time, volcanic activity has also started forming phreatomagmatic explosions, basalt magmatism and postvolcanic geyser activities in the region (Németh et al. 2001). Only the latter is represented in the study area (Albert et al. 2018).

During the Pleistocene, climatic fluctuations created variable landforms and peculiar sediments like aeolian loess sheets and alluvial fans. The area was under periglacial conditions during the glacial periods, and wind erosion was dominant. The basin of Lake Balaton formed during this time due to the combined effects of gradual tectonic subsidence and deflation (Cserny and Nagy-Bodor 2000). In the more humid interglacial periods, fluvial erosion was dominant and the alluvial fans prograded into the Balaton Basin. The slow uplifting of the area during the Pleistocene helped the meteoric water to form caves in the carbonates and allowed the southflowing creeks to cut through ridges creating spectacular landforms on the surface (Korbély 2011).

\section{The Applied Assessment Models}

The assessment of the study area was carried out with the MGAM method, which practically involves the quantitative method of the Geosite Assessment Model (GAM). GAM has already been successfully used in some countries, including Hungary (e.g., Szepesi et al. 2017). The geotourism potential of the evaluated geosite is described by the sum of two main variable groups: the main values (MV) and the additional values (AV). The main values group consists of the scientific/educational (VSE), scenic/aesthetic (VSA) and protection (VPr) subgroups, while the additional values group is formed by the functional
(VFn) and tourism (VTr) subgroups (Table 1). The MV groups contain 12 , and the $\mathrm{AV}$ groups contain 15 parameters, which are called indicators altogether. Geosites are evaluated by scoring these indicators with 0 (the worst), $0.25,0.5,0.75$ and 1 (the best) marks. The final GAM values are calculated using the following equations:

$$
\begin{gathered}
M V=V S E+V S A+V P r \\
A V=V F n+V T r \\
G A M=M V+A V .
\end{gathered}
$$

These are the final results of a GAM assessment (Vujičić et al. 2011). The detailed process of scoring is found in Tables 1 and 2.

Although this is rather an objective way of assessment, a geosite usually holds some other kinds of values that are not considered in this method. There might be other important factors, such as psychological, historical, entertaining and religious characters that could be subjects of individual preference. In this sense, the geological "story" is superimposed by personal experiences, memories and aims. All these aspects are gathered in the Im weight of M-GAM.

The authors of M-GAM asked 96 geotourists at 3 different geosites to give scores for the $27 \mathrm{GAM}$ indicators according to their opinion (on the scale of $0,0.25,0.5,0.75$ and 1). It was complemented in 2015, when a group of 197 visitors filled the questionnaires but not at the same sites (Božić and Tomić 2015). The visitor's votes were then averaged to get the Im value of a certain indicator. They calculated the M-GAM value of a site by multiplying the GAM scores by the Im values:

$M G A M=\operatorname{Im}(G A M)=\operatorname{Im}(M V+A V)$.

With the use of this weighting method, the assessment includes the opinions of all interviewed geotourists strengthening the objectivity of the evaluation.

The authors of M-GAM used scatterplot matrices (Fig. 2) in order to express and visualise differences between the GAM and M-GAM values. The position of geosites in different matrix fields refers to their current status in geotourism. Values on the horizontal and vertical axes show the main and additional value scores, respectively; the higher the score, the more significant the geosite is. Although the Im values identified by Tomić and Božić (2014) helped to highlight the expectations and interests of tourists generally, it referred to the whole Lazar Canyon area, and to an even larger territory in their subsequent work (Božić and Tomić 2015). The present study used another approach of the MGAM method by measuring the Im weights for all the geosites individually using on-site and online questionnaires. In this way, we were able to observe the spatial variability of the Im values, that is, the Im differences between each examined geosite. 


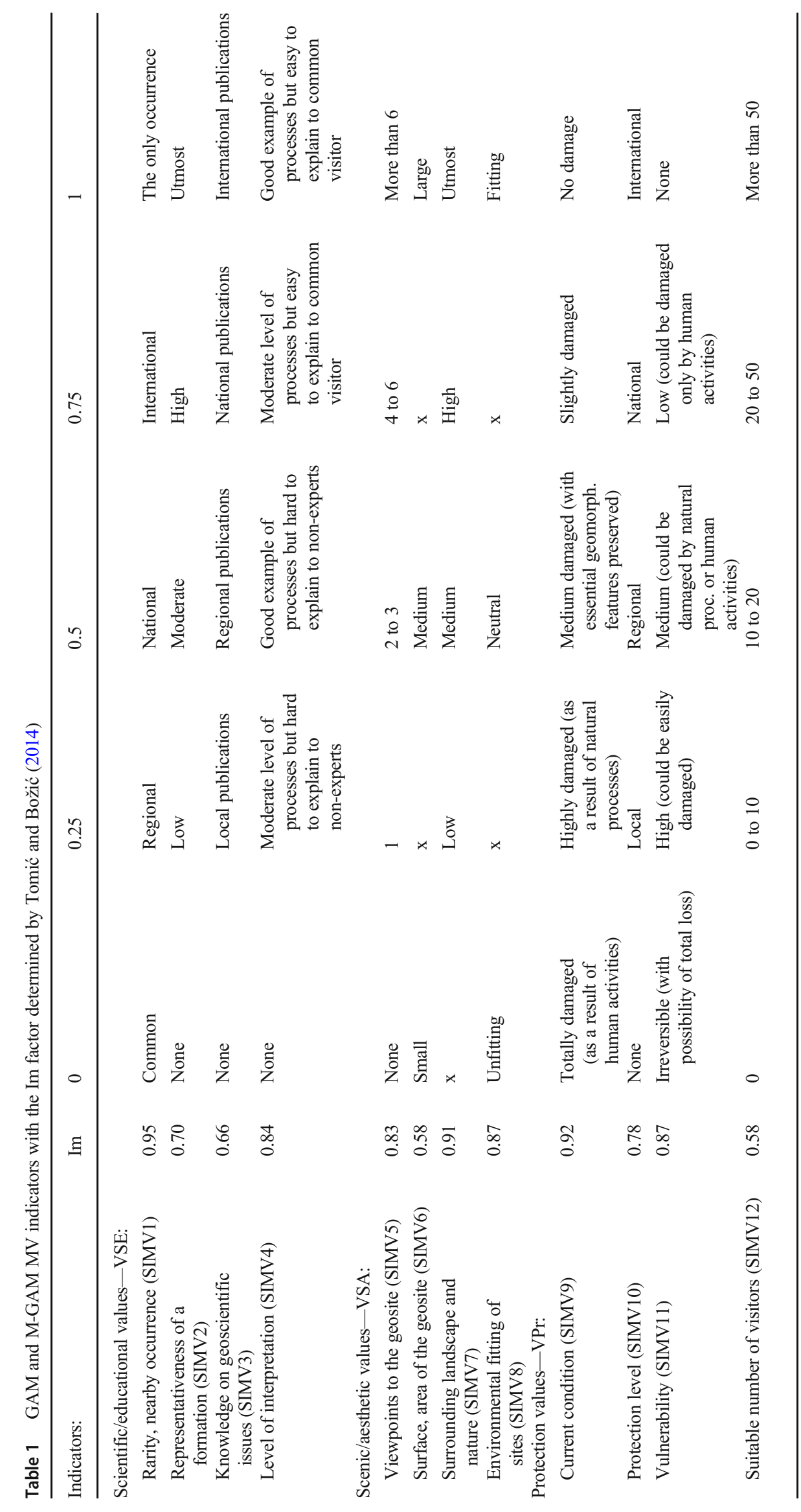




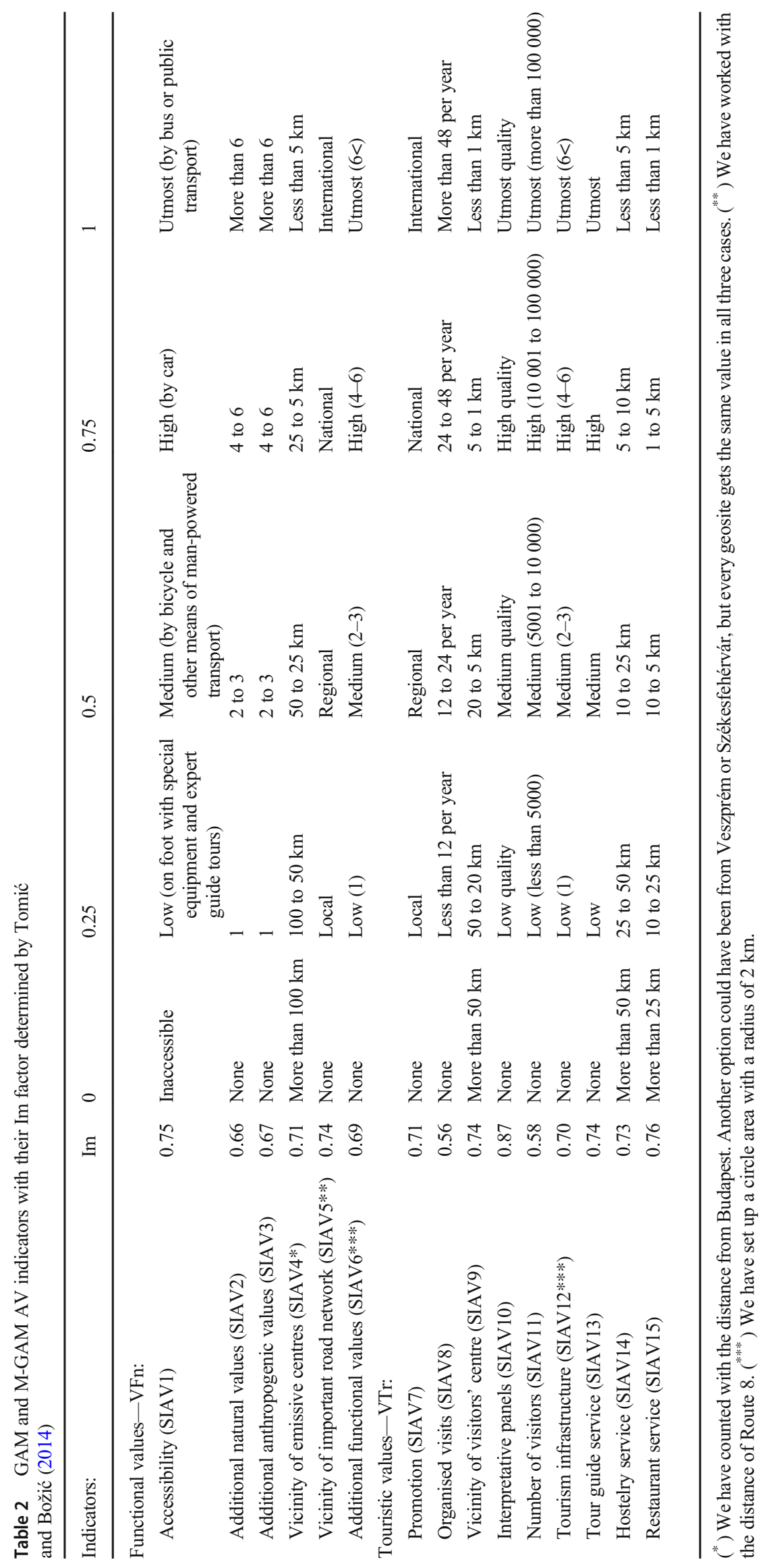


Fig. 2 Scatterplot matrices in Tomić and Božić (2014). GAM values are on the left and MGAM values on the right

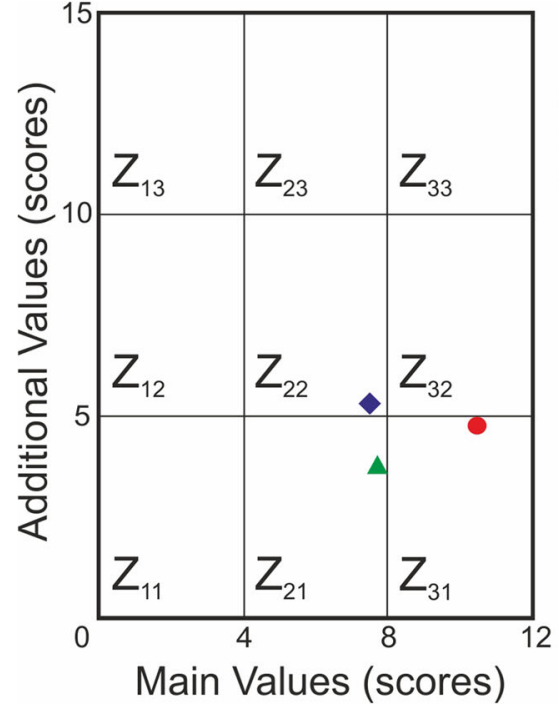

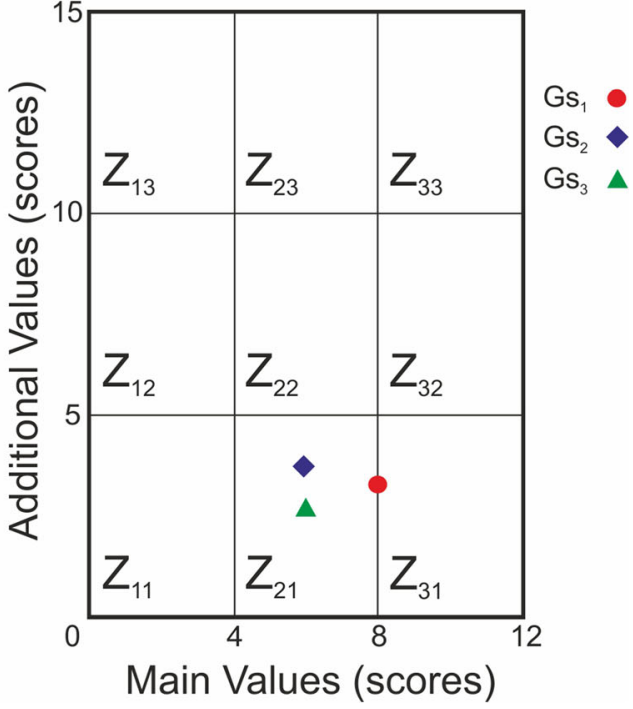

\section{Collecting and Processing Data from the Study Area}

By asking geotourists to fill out questionnaires at every examined geosite, we have the opportunity to produce geositespecific data: the Im weights are determined independently of each other. A comparison of the results has been done to analyse the spatial variability of geosite assessment and to determine the unique character of each location. It must be noted that collecting site-specific answers requires either personnel or some infrastructure. Since the selected nine locations are not all frequently visited by tourists, it was decided to set some infrastructure at all sites by placing waterproof sheets on information boards calling for online questionnaire fill, and collect the answers mainly through them. The total number of fills gathered is 247 during a 14-month period.

\section{Online Interviewing}

To produce data comparable with other geosites in Hungary and especially with the originally published Lazar Canyon territory, our questionnaire was based on the original descriptions of GAM/M-GAM and Im. We asked the visitors how important they consider each indicator of the model. Tourists were not differentiated throughout the survey, although we collected demographic data for further research. We have designated the nine most important geosites of the area according to the preliminary GAM-M-GAM evaluation (Fig. 3). Most of them have relatively developed infrastructure (explanatory signs, information boards, benches, bins, parking places, etc.), but they might be utilised better with the help of this research.

To ensure that results come from only tourists or locals who definitely visited and know the geosite, we put laminated paper sheets next to the geosites (e.g., on the wooden frame of an information board). On each of these sheets, there was a short description, a QR-code and a link to a site-specific Google Form that made the on-site fill possible. On the webform, our research topic's importance was shortly described and all 27 indicator-related questions were asked. Visitors had to evaluate every indicator on a 0 -to- 1 scale: 0 -not important, 0.25-rather not important, 0.5 -moderately important, 0.75-rather important, 1 -important. We have provided a box where geotourists, who are interested in this project, may type their e-mail address and we give them information about our work.

\section{On-Site Interviewing}

On-site interviewing took place at sites where the number of online fills did not rise in the expected pace (i.e., 2-4 fills per month). These were typically the ones with low level of infrastructure. The paper-based questionnaire was the same as the online version. This type of interviewing was not so successful as we expected: only $\sim 10 \%$ of the fills were collected in this way. Most of the visitors we asked were not confident and enthusiastic about scientific topics: they may have liked solitude when filling these types of questionnaires.

\section{Results of the Evaluation}

The interviewing took place between July 2018 and September 2019. During this time, 247 fills were collected from the designated geosites (Fig. 4). The tool for data processing, analysis and visualisation was MS Excel. The Im value that indicates the importance of a geosite was calculated in two ways: (1) the calculation of the arithmetic mean of fills per indicator per site was quasi-similar to the original MGAM methodology, (2) each of the fills was considered as an individual assessment, and a site-wise statistical evaluation 


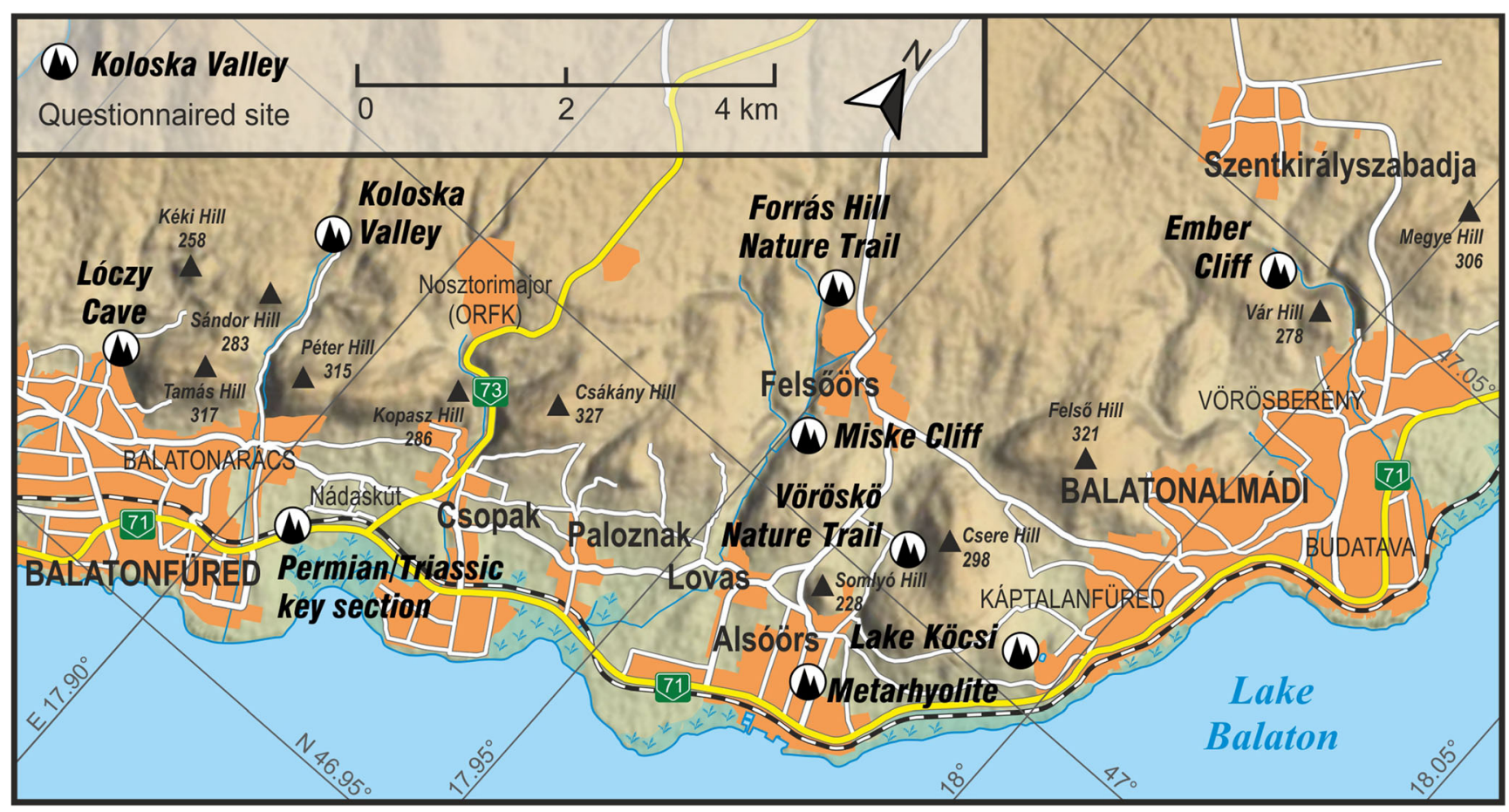

Fig. 3 Map of the examined geosites

was done on the dataset. With neither of the methods, visitors were not differentiated: an answer of an expert weighed as much as an answer of a laic geotourist.

\section{The Local Im (Importance) Values}

By summarising Im data from each geosite, we get unique geosite-specific values for each GAM indicator. If we insist on using the originally published methodology of the MGAM evaluation, a further averaging of the Im values would be necessary for all the indicators. Instead, we compared our data with the available Im weights from elsewhere to analyse the differences.

According to the original description of M-GAM (Tomic and Božić 2014), the Im values reflect a general opinion about the importance of the model's indicators. They suggested that the identified Im weights can make the evaluation more objective by pointing out those values, which are of paramount importance for tourists. Several studies applied the determined values, including ourselves during the assessment around
Fig. 4 The number of fills per geosite

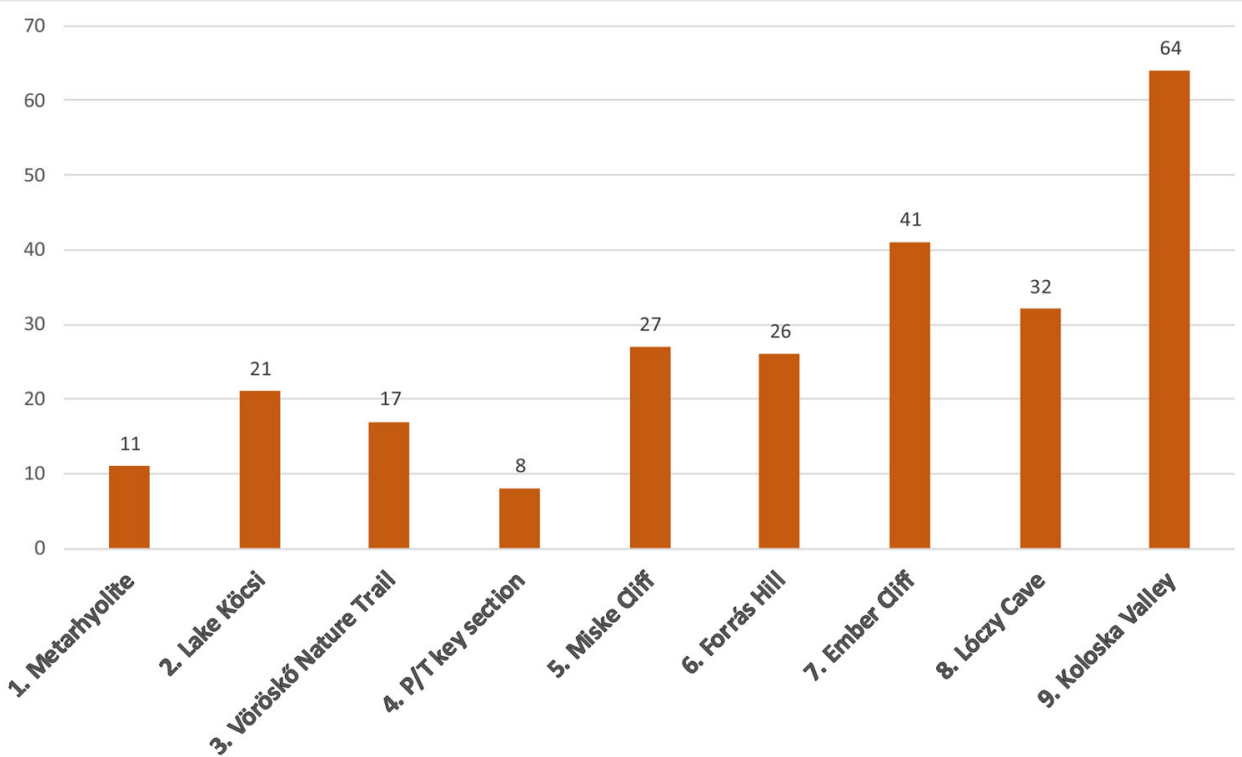




\begin{tabular}{|c|c|c|c|c|c|c|c|c|c|c|c|}
\hline $\begin{array}{r}\text { Geosite } \\
\text { Indicator }\end{array}$ & \begin{tabular}{|c|} 
Importance \\
2014 \\
\end{tabular} & \begin{tabular}{|c|} 
Importance \\
2015 \\
\end{tabular} & $\begin{array}{l}\text { 1. Meta- } \\
\text { rhyolite }\end{array}$ & 2. L. Köcsi & \begin{tabular}{|l|} 
3. Vöröskö \\
Nature Trail \\
\end{tabular} & \begin{tabular}{|c|} 
4. PIT \\
key section
\end{tabular} & $\begin{array}{l}\text { 5. Miske } \\
\text { Cliff }\end{array}$ & $\begin{array}{l}\text { 6. Forrás } \\
\text { Hill }\end{array}$ & $\begin{array}{l}\text { 7. Ember } \\
\text { Cliff }\end{array}$ & $\begin{array}{l}\text { 8. Lóczy } \\
\text { Cave }\end{array}$ & $\begin{array}{l}\text { 9. Koloska } \\
\text { Valley }\end{array}$ \\
\hline $\begin{array}{l}\text { MV1 - } \\
\text { Rarity }\end{array}$ & & & & & & & & & & & \\
\hline $\begin{array}{l}\text { MV2 - } \\
\text { Represen- } \\
\text { tativeness }\end{array}$ & & & & & & & & & & & \\
\hline $\begin{array}{c}\text { MV3 - } \\
\text { Geosci. } \\
\text { knowledge }\end{array}$ & & & & & & & & & & & \\
\hline $\begin{array}{c}\text { MV4 - } \\
\text { Interpre- } \\
\text { tativeness }\end{array}$ & & & & & & & & & & & \\
\hline $\begin{array}{c}\text { MV5 - } \\
\text { Viewpoints }\end{array}$ & & & & & & & & & & & \\
\hline $\begin{array}{c}\text { MV6 - } \\
\text { Surface }\end{array}$ & & & & & & 0.47 & & & & & \\
\hline $\begin{array}{l}\text { MV7 - } \\
\text { Surrounding } \\
\text { landscape } \\
\text { and nature }\end{array}$ & & & & & & 0.47 & & & & & \\
\hline $\begin{array}{l}\text { MV8 - } \\
\text { Environm. } \\
\text { fitting }\end{array}$ & & & & & & & & & & & \\
\hline $\begin{array}{l}\text { MV9 - } \\
\text { Current } \\
\text { condition }\end{array}$ & & & & & & & & & & & \\
\hline $\begin{array}{l}\text { MV10 - } \\
\text { Level of } \\
\text { protection }\end{array}$ & & & & & & & & & & & \\
\hline $\begin{array}{c}\text { MV11 - } \\
\text { Vulnerability }\end{array}$ & & & & & & & & & & & \\
\hline $\begin{array}{c}\text { MV12 - } \\
\text { Suitable } \\
\text { number } \\
\text { of visitors }\end{array}$ & & 0.53 & & 0.45 & & & & & & & \\
\hline
\end{tabular}

Fig. 5 The global importance values of the MV indicators (2014 and 2015) based on Tomić and Božić (2014) and Božić and Tomić (2015), compared with the present results

Csopak village in 2017 (Pál and Albert 2018). This new method seemed to show more realistic results owing to the GAMmodifying Im factor. The analysis of the difference between the two models' results gave the opportunity to give hints about development strategies, but the question of the relevance of the averaged weights have emerged.

Tomić and Božić published new importance values in 2015 (with 293 fills). These were produced by summing the 96 fills from the original survey from the Lazar Canyon and adding
197 from other sites. The difference between the two Im weights is surprisingly high, suggesting that the $\mathrm{Im}$ value is not a constant, but a variable that may have spatial dependency. However, these aspects were not mentioned in the publications.

The Im values of the two archive surveys and the Im-s of the present survey (Figs. 5 and 6) are greatly varying. There are two columns for the global factors (blue circles) and nine columns for the examined geosites in the Balaton Uplands (red circles). 


\begin{tabular}{|c|c|c|c|c|c|c|c|c|c|c|c|}
\hline $\begin{array}{l}\text { Geohely. } \\
\text { Paraméter }\end{array}$ & \begin{tabular}{|c|} 
Importance \\
2014 \\
\end{tabular} & \begin{tabular}{|c} 
Importance \\
2015 \\
\end{tabular} & $\begin{array}{l}\text { 1. Meta- } \\
\text { rhyolite }\end{array}$ & 2. L. Köcsi & $\begin{array}{l}\text { 3. Vöröskö } \\
\text { Nature Trail }\end{array}$ & \begin{tabular}{|c|c|}
$4 . P / T$ \\
key section
\end{tabular} & $\begin{array}{l}\text { 5. Miske } \\
\text { Cliff }\end{array}$ & $\begin{array}{l}\text { 6. Forrás } \\
\text { Hill }\end{array}$ & $\begin{array}{l}\text { 7. Ember } \\
\text { Cliff }\end{array}$ & $\begin{array}{l}\text { 8. Lóczy } \\
\text { Cave }\end{array}$ & $\begin{array}{l}\text { 9. Koloska } \\
\text { Valley }\end{array}$ \\
\hline $\begin{array}{c}\text { AV1 - } \\
\text { Accessibility }\end{array}$ & & & & & & & 0.38 & & $\begin{array}{c}\bigcirc \\
0.29 \\
\end{array}$ & & \\
\hline $\begin{array}{l}\text { AV2- } \\
\text { Additional } \\
\text { natural } \\
\text { values }\end{array}$ & $.66)$ & & & & & & 0.51 & & 0.45 & & \\
\hline $\begin{array}{c}\text { AV3- } \\
\text { Additional } \\
\text { anthropog. } \\
\text { values } \\
\end{array}$ & & & & 0.4 & & & 0.37 & & $\begin{array}{c}\bigcirc \\
0.29\end{array}$ & 0.48 & \\
\hline $\begin{array}{l}\text { AV4- } \\
\text { Vicinity of } \\
\text { emissive } \\
\text { centres }\end{array}$ & & & & & & & & & 0.48 & & \\
\hline $\begin{array}{l}\text { AV5- } \\
\text { Vicinity of } \\
\text { important } \\
\text { road netw. }\end{array}$ & & & & & & & $\underset{0.32}{\bigcirc}$ & & 0.38 & & 0.44 \\
\hline $\begin{array}{c}\text { Av6- } \\
\text { Additional } \\
\text { functional } \\
\text { values } \\
\end{array}$ & & & 0.39 & 0.45 & & & 0.34 & & 0.34 & & 0.41 \\
\hline $\begin{array}{l}\text { AV7 - } \\
\text { Promotion }\end{array}$ & & & & & & & 0.41 & & 0.47 & & \\
\hline $\begin{array}{c}\text { AV8- } \\
\text { Organized } \\
\text { visits }\end{array}$ & & & & 0.42 & & 0.44 & 0.38 & & 0.42 & & 0.41 \\
\hline $\begin{array}{l}\text { AV9- } \\
\text { Vicinity of } \\
\text { visitors' } \\
\text { centre } \\
\end{array}$ & & & & 0.37 & & 0.38 & 0.33 & & 0.39 & & 0.46 \\
\hline $\begin{array}{c}\text { AV10 - } \\
\text { Interpret. } \\
\text { panels }\end{array}$ & & & & & & & & & & & \\
\hline $\begin{array}{l}\text { AV11 - } \\
\text { Number of } \\
\text { visitors }\end{array}$ & & & 0.46 & 0.42 & 0.44 & 0.19 & $\begin{array}{c}\bigcirc \\
0.25\end{array}$ & 0.39 & 0.38 & .51 & 0.41 \\
\hline $\begin{array}{c}\text { AV12- } \\
\text { Tourism } \\
\text { infra- } \\
\text { structure }\end{array}$ & & & & & & & 0.38 & & & & \\
\hline $\begin{array}{c}\text { AV13 - } \\
\text { Tour guide } \\
\text { service }\end{array}$ & & & & 0.38 & & $\bigcirc_{0.41}$ & $\begin{array}{c}\bigcirc \\
0.29\end{array}$ & & $\underset{0.38}{\bigcirc}$ & & 0.44 \\
\hline $\begin{array}{l}\text { AV14 - } \\
\text { Hostelry } \\
\text { service }\end{array}$ & & & 0.39 & $\underset{0.35}{\bigcirc}$ & 0.41 & $\begin{array}{c}0 \\
0.25\end{array}$ & $\underset{0.32}{\bigcirc}$ & 0.4 & $\underset{0.35}{\bigcirc}$ & 0.35 & 0.41 \\
\hline $\begin{array}{l}\text { AV15 - } \\
\text { Restaurant } \\
\text { service }\end{array}$ & $(1$ & & 0.41 & 0.36 & 0.40 & $\begin{array}{c}\bigcirc \\
0.28\end{array}$ & $\underset{0.28}{\bigcirc}$ & 0.42 & $\underset{0.37}{\bigcirc}$ & 0.35 & 0.4 \\
\hline
\end{tabular}

Fig. 6 The global importance values of the AV indicators (2014 and 2015) based on Tomić and Božić (2014) and Božić and Tomić (2015), compared with the present results

There is even larger variability between the global and local AV Im-s (Fig. 6) than in the case of MV Im-s (Fig. 5). The determined values expressively refer to the character of a geosite: for example, the difficulty level of accessibility (if easy, larger score, if hard, lower score) or tourism infrastructure (if exists, higher score, if does not exist, lower score).

The Im values for the study area represent the weight of the certain indicator, but by comparing the values calculated for 
the sites, the spatial variance of the indicators can also be given (Table 3). For this, we used the VAR.P function of Excel.

\section{Site-Wise Statistical Evaluation}

The individual Im values of an interviewed visitor produce a single M-GAM evaluation for the given site. Because of this, the number of questionnaire fills is equal to the number of individual assessments available at a certain geosite. By plotting these unique assessments into a scatterplot diagram of MVs and AVs (considered as independent variables), we can visualise how differently the interviewed visitors think about the geotourism potential of a geosite (Fig. 7).

When plotting these values as $x(\mathrm{MV}), y(\mathrm{AV})$ functions, we get point clouds with various shapes in the scatterplot diagrams. These diagrams show how the visitors interpret the importance and significance of each geosite, and how these evaluations differ from each other. It is evident that the scientific value (MVs) and local infrastructure value (AVs) fit differently to the visitors' expectations and needs, but the shapes of the clouds statistically reflect to all the interviewed visitors' opinion about the examined sites. The point clouds can be differentiated based on their shape: $\mathrm{LI}=$ large isometric; $\mathrm{SI}$ $=$ small isometric $; \mathrm{EA}=$ elongated, additional values dominat ed; $\mathrm{EM}=$ elongated, main values dominated.

The large and isometric (regular shaped) clouds refer to the diverse interests, expectations and scientific-infrastructural needs of geotourists. The variance $\left(\sigma^{2}\right)$ is relatively high among these values (e.g., Lake Köcsi and Miske Cliff), because those who go there weight the indicators very

Table 3 Variance of the MV and AV indicators over the whole study area

\begin{tabular}{|c|c|c|c|c|c|}
\hline a) & MV indicators & $\sigma^{2}$ & b) & AV indicators & $\sigma^{2}$ \\
\hline & MV1 & 0.009 & & AV1 & 0.014 \\
\hline & MV2 & 0.009 & & AV2 & 0.003 \\
\hline & MV3 & 0.011 & & AV3 & 0.009 \\
\hline & MV4 & 0.004 & & AV4 & 0.004 \\
\hline & MV5 & 0.005 & & AV5 & 0.013 \\
\hline & MV6 & 0.003 & & AV6 & 0.006 \\
\hline & MV7 & 0.011 & & AV7 & 0.004 \\
\hline & MV8 & 0.005 & & AV8 & 0.012 \\
\hline & MV9 & 0.001 & & AV9 & 0.016 \\
\hline & MV10 & 0.003 & & AV10 & 0.004 \\
\hline & MV11 & 0.002 & & AV11 & 0.009 \\
\hline & \multirow[t]{4}{*}{ MV12 } & 0.012 & & AV12 & 0.019 \\
\hline & & & & AV13 & 0.025 \\
\hline & & & & AV14 & 0.002 \\
\hline & & & & AV15 & 0.002 \\
\hline
\end{tabular}

differently, which means that the people who visited the site and filled the form had varying knowledge about the site. This could refer to that the geosite is not well communicated or promoted, and its features do not fit to the visitors' expectations. This situation could be treated by clear, well-designed commercial material, internet sources and interpretive panels.

If the cloud is small and isometric, the visitors have quite similar opinions (either good or bad) of the features of a certain geosite (e.g., P/T key section and Forrás Hill). In this case, each individual assessment gets nearly the same M-GAM value. This means that only those people who visited the site (filled out the form) were quite equally aware of the AV and MV state of the geosite.

When the shape of the point set is not regular, we can differentiate the visitors according to the MV and AV values. These elongated clouds could refer to different evaluation groups, which can be categorised by a linear function model fitted on the point cloud.

(1) The negative line-fit: lower values on the $y_{(\mathrm{AV})}$ axis but higher on the $x_{(\mathrm{MV})}$ axis refer to visitors who prefer the scientific values over the infrastructural ones, but there are others who consider geoscientific features not so important, so they gave lower Im scores for the $x_{(\mathrm{MV})}$ and weight the AVs as important indicators. If both types occur on the scatterplot, a line with negative steepness would fit on the points, meaning that people who expect very different things visit the site. Practically, the geosite is not well communicated

(2) The positive line-fit: the lower values on the $y_{(\mathrm{AV})}$ axis have generally lower values on the $x_{(\mathrm{MV})}$ axis as well and occur together with assessments having higher values on both axes. A line with positive steepness would fit on the points meaning that there are people who are generally unsatisfied and people who are generally satisfied with both MVs and AVs. Normally, this situation is the most common. Finding the good management of these sites is quite difficult, because there is a need for infrastructural and scientific development too

When analysing these non-isometric elongated clouds, we can use the steepness $(S)$ of the linear functions plotted on the MGAM score set. This steepness refers to the difference between the visitors' opinions. We can determine if there is higher demand for scientific or communicational-infrastructural development: when the steepness is greater than 1 , additional values, if less than 1 , main values are more important for the visitors in general.

The $R^{2}$ coefficient shows the goodness of the fit of a linear function on the personal assessment scores. If $R^{2}<0.2$, the fit is rather uncertain. If the $R$-square value is high, the cloud fits to the trend line and we can draw conclusions about further strategies. For example, the Koloska Valley geosite has nearly the highest coefficient value $\left(R^{2}=0.353\right)$ and the steepness is 

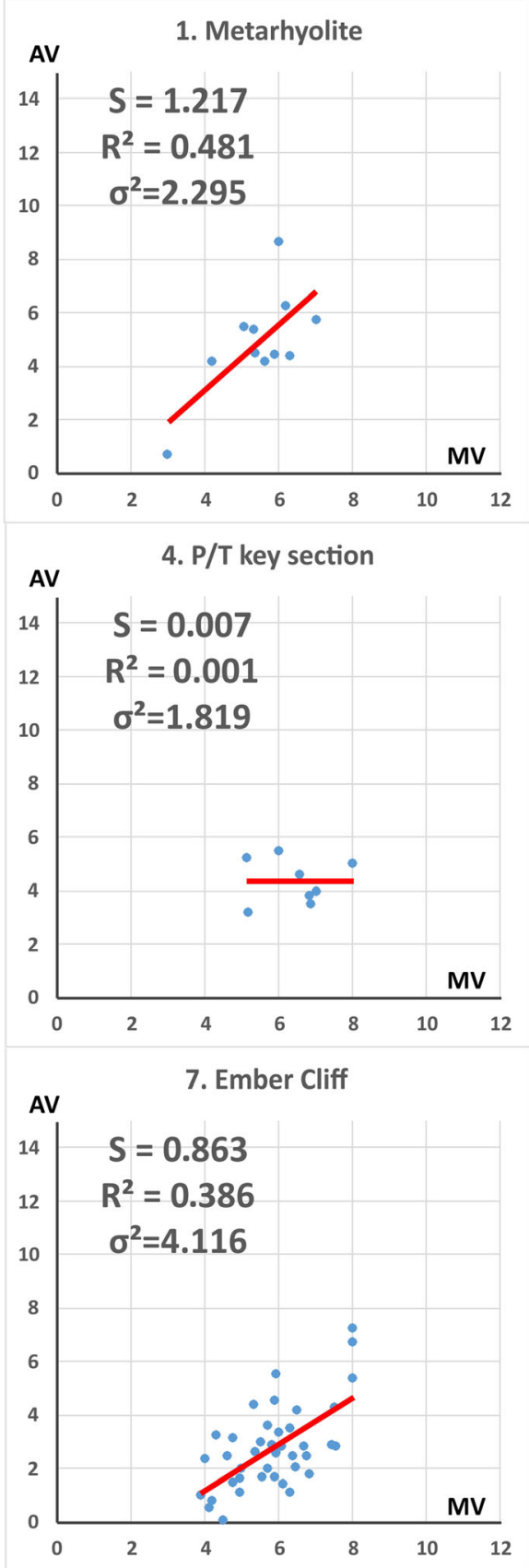

2. Lake Köcsi

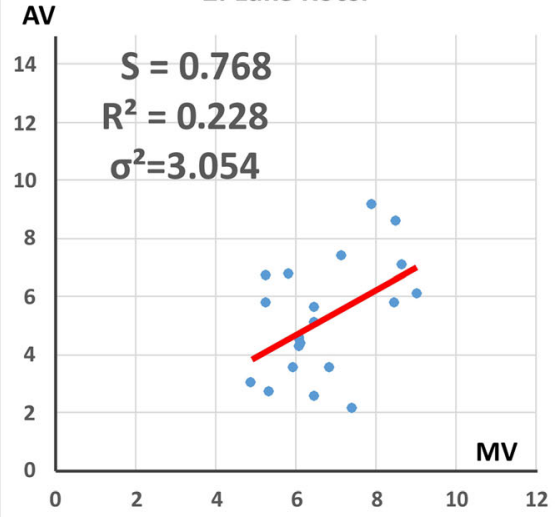

5. Miske Cliff

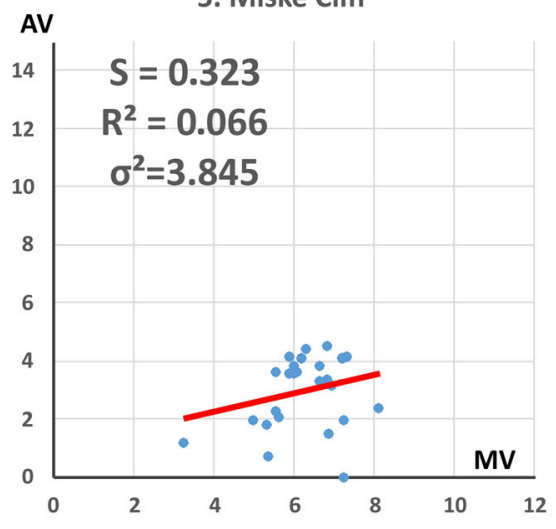

8. Lóczy Cave

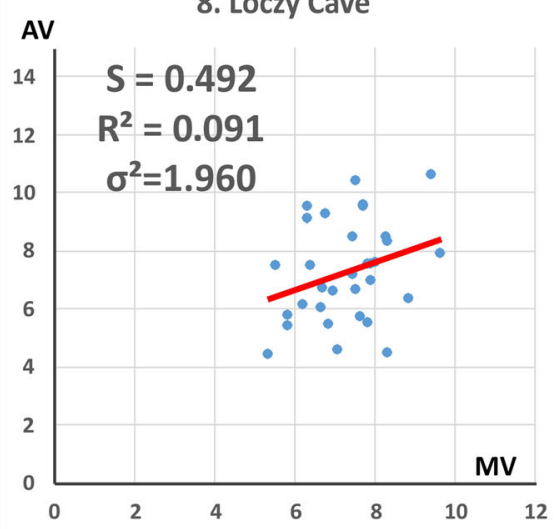

3. Vöröskő Nature Trail

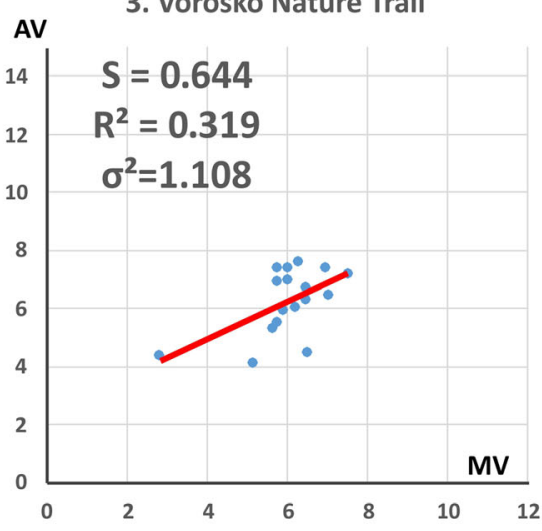

6. Forrás Hill

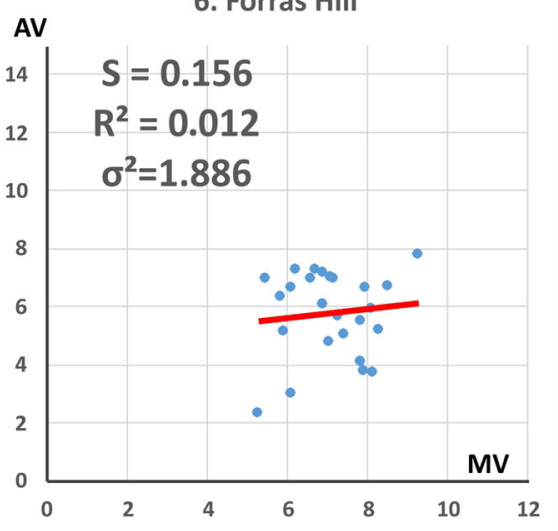

9. Koloska Valley

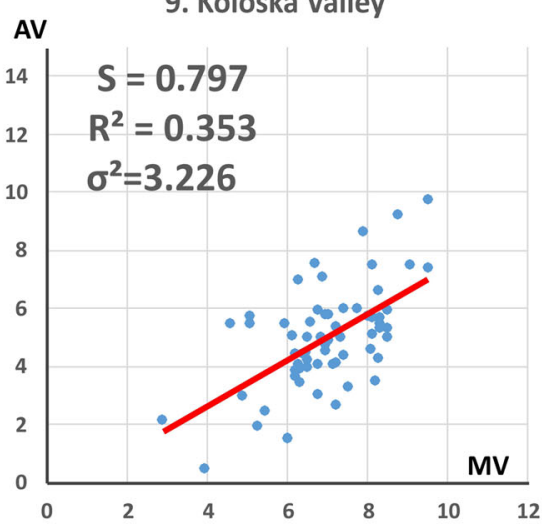

Fig. 7 The diagram showing all unique M-GAM assessments. $S$ is the steepness of the linear function $f(\mathrm{MV})=\mathrm{AV}$ fitted on the point cloud with the least square method, $R^{2}$ is the coefficient of determination and $\sigma^{2}$ is the variance of each dataset. If $R^{2}<0.2$, the linear fit is rather uncertain.

0.797. This means that the site is nearly balanced: the visitors are equally satisfied with both Main and Additional Values but to a different extent. However, the less-than-one steepness shows that the site would need consideration about enhancing the scientific interpretation and promoting to match the management plan with the visitors' expectations.

The $\sigma^{2}$ is the variance of the dataset. This value shows how the plotted values differ from the statistical mean of the whole set of fills on each geosite. It also shows the extent of the difference of the visitors' personal evaluations.

\section{Discussion}

We have gathered 247 fills varying between 8 and 64 per site (Fig. 4). As it is not a statistical amount of data, we consider this study as an exploratory research. We found that interviewing at a geosite is a hard task because of the sporadic visits and a common indifference among tourists concerning such queries. The length of the questionnaire can also be caused for the relatively small number of answers: thinking over 27 questions and answering them requires patience. 
However, the installation of QR codes directing to the online questionnaire seemed to be working as $90 \%$ of the collected data were gathered through this way.

In Table 4, results, consequences and proposed development strategies are summarised regarding the nine examined sites. The current state of the geosites is derived from the individual Im values, while the development strategies are summarised from the site-wise statistical evaluation.

The variances $\left(\sigma^{2}\right)$ of the indicators show that geotourists consider each geosite important due to different marks, facilities and services (Table 3). This proves the uniqueness of the sites and highlights the importance of separate assessment factors. The sigma-square values in Table 3 are determined for the whole study area and, thus, they represent the spatial variance of the indicators. Among the MV indicators, MV12 (suitable number of visitors) shows the largest spatial variance $\left(\sigma^{2}=0.012\right)$ and the MV9 (current state) the smallest one $\left(\sigma^{2}=0.001\right)$. Considering the AV indicators, the AV13 (tour guide service) has the largest $\left(\sigma^{2}=0.025\right)$ and the AV14 and 15 (hostelry and restaurant services) the smallest $\left(\sigma^{2}=0.002\right)$ spatial variance, although the latter ones are considered equally unimportant by the answerers with Im values barely reaching 0.4 (Fig. 6). However, the AV10 (interpretation panels), showing also a small spatial variability $\left(\sigma^{2}=0.004\right)$, was the most important indicator for the visitors with $\mathrm{Im}$ values around 0.9 at all the 9 sites (Fig. 6 and Table 3). Our results also show that there is a large difference in the variance of the personal evaluations ranging from 1.108 (Vöröskö Nature Trail) to 4.116 (Ember Cliff) on the examined sites (Fig. 7 and Table 4). These support our hypothesis about the spatial variability of the geosite assessment using the M-GAM method.

The collection of data continues on these nine and other selected sites on the adjacent areas of the BBG. The increasing number of fills does not only improve the statistical parameters of the survey but also if it lasts long enough and lives through several tourist seasons it can detect the change of the Im value in time. We suppose that besides the spatial variability, the modificatory effect of time can also be a property of geosite assessment because infrastructural developments and good promotional solutions can modify the calculated importance values. We hope that conclusions can be drawn about infrastructural and/or scientific questions in the following years (e.g., building of interpretive panels, visitors' centre and development of geoeducation). In the case of two examined sites, Lóczy Cave and Vöröskő Nature Trail, large infrastructural development is to be built, so the variability of Im values in time could be examined there.

Table 4 Current state of the geosites and individual development strategies. Point cloud shapes: LI: large isometric; SI: small isometric; EA: elongated, additional values dominated; EM: elongated, main values dominated (see Fig. 7)

\begin{tabular}{|c|c|c|c|c|}
\hline Geosite & Point cloud & Results & Current state & Development strategies \\
\hline Metarhyolite & EA & $\begin{array}{l}S: 1.217 \\
R^{2}: 0.481 \\
\sigma^{2}: 2.295\end{array}$ & $\begin{array}{l}\text { No tourism infrastructure despite the good } \\
\text { MV Im-s. It has good functional values } \\
\text { (located in Alsóörs). }\end{array}$ & $\begin{array}{l}\text { Interpretive panels, benches, dustbins or other } \\
\text { tourism facilities are needed to reach balance } \\
\text { with the scientific values. }\end{array}$ \\
\hline Lake Köcsi & LI & $\begin{array}{l}S: 0.768 \\
R^{2}: 0.228 \\
\sigma^{2}: 3.054\end{array}$ & $\begin{array}{l}\text { The site is not well-promoted (large isometric } \\
\text { cloud). The tourism infrastructure is not } \\
\text { maintained correctly. }\end{array}$ & $\begin{array}{l}\text { Clear and well-designed commercial materials } \\
\text { are needed to filter the diverse expectations } \\
\text { of visitors. }\end{array}$ \\
\hline Vöröskő Nature Trail & EM & $\begin{array}{l}S: 0.644 \\
R^{2}: 0.319 \\
\sigma^{2}: 1.108\end{array}$ & $\begin{array}{l}\text { Good AV Im-s because of the neighbouring } \\
\text { outdoor theatre. The scientific values are } \\
\text { not balanced with it. }\end{array}$ & $\begin{array}{l}\text { A visitors' centre is being built now. It will put } \\
\text { more emphasis on geoheritage-MV Im-s } \\
\text { and AV Im-s will be balanced. }\end{array}$ \\
\hline $\mathrm{P} / \mathrm{T}$ key section & SI & $\begin{array}{l}S: 0.007 \\
R^{2}: 0.001 \\
\sigma^{2}: 1.819\end{array}$ & The MV Im-s and AV Im-s are well-balanced. & $\begin{array}{l}\text { The location is not suitable for more tourism } \\
\text { infrastructure. A car parking could make } \\
\text { visiting more comfortable. }\end{array}$ \\
\hline Miske Cliff & LI & $\begin{array}{l}S: 0.323 \\
R^{2}: 0.066 \\
\sigma^{2}: 3.845\end{array}$ & $\begin{array}{l}\text { Good MV Im-s but poor AV Im-s because } \\
\text { of the lack of tourism infrastructure. }\end{array}$ & $\begin{array}{l}\text { Interpretive panels, good commercial materials } \\
\text { and well-marked hiking routes are needed, } \\
\text { it is hard to find the location from Felsöörs. }\end{array}$ \\
\hline Forrás Hill & SI & $\begin{array}{l}S: 0.156 \\
R^{2}: 0.012 \\
\sigma^{2}: 1.886\end{array}$ & $\begin{array}{l}\text { The site is not well-promoted (large isometric } \\
\text { cloud). The tourism infrastructure is not } \\
\text { maintained correctly. }\end{array}$ & $\begin{array}{l}\text { The MV Im-s and AV Im-s seem to be in } \\
\text { balance, but clear promotion is needed to } \\
\text { reach a regular-shaped point cloud }\end{array}$ \\
\hline Ember Cliff & EM & $\begin{array}{l}S: 0.863 \\
R^{2}: 0.386 \\
\sigma^{2}: 4.116\end{array}$ & $\begin{array}{l}\text { MV Im-s are good, but AV Im-s are very } \\
\text { low-no tourism infrastructure. }\end{array}$ & $\begin{array}{l}\text { Interpretive panels and better-quality hiking } \\
\text { trails would improve the experience of the } \\
\text { visitors. }\end{array}$ \\
\hline Lóczy Cave & LI & $\begin{array}{l}S: 0.492 \\
R^{2}: 0.091 \\
\sigma^{2}: 1.960\end{array}$ & $\begin{array}{l}\text { The site is not well-promoted (large isometric } \\
\text { cloud). Many visiting tourists do not know } \\
\text { what to expect in the cave. }\end{array}$ & $\begin{array}{l}\text { Better geosite promotion is needed. A visitors' } \\
\text { centre is being built now. It may enhance the } \\
\text { dissemination of scientific values. }\end{array}$ \\
\hline Koloska Valley & EM & $\begin{array}{l}S: 0.797 \\
R^{2}: 0.353 \\
\sigma^{2}: 3.226\end{array}$ & $\begin{array}{l}\text { The site is visited not only for the geological } \\
\text { heritage - it is a nice picnic area. }\end{array}$ & $\begin{array}{l}\text { Better marketing could point out the large } \\
\text { geotourism potential of the valley. } \\
\text { Improvement of the infrastructure is needed. }\end{array}$ \\
\hline
\end{tabular}




\section{Conclusion}

Perfect assessment models do not exist. At least the subjectivity of the evaluating person always emerges while inconsistent and uncertain data and data sources may cause precarious and misleading results. We have used the M-GAM model during the analysis. The determination of the importance ( $\mathrm{Im}$ ) values should take the spatial variability of the evaluation into consideration. To count with it, we needed to collect visitors' opinions from each of the nine examined geosites in the research area in the Balaton Uplands. We demonstrated that the Im value of M-GAM is suitable for determining the visitors' opinion about the current state of the geosites. For this, the assessment was completed with the acquisition of on-site and online questionnaires at nine geosites of the BBG. The difference of the original and the newly determined Im values is explained by the difference between their meanings. While the previously published Im values are aimed at expressing a general weight for the GAM indicators for an examined area, the ones presented in this study are unique weights expressing the visitors' expectations for each examined geosite. It can be analysed to plan a better infrastructure or to put more emphasis on the interpretation of the scientific content.

When interviewing, it is very important to ask wellcomposed and clear questions. However, this GAM-based method is quite complex with its 27 indicators and it should also be considered to work out, or apply a less complex model for on-site questionnaires.

Among the improvement of geosite assessment, our aim is to emphasise the role of geoheritage. Effective protection should always precede developments. Proper assessment using different criteria helps to compare geosites that are suitable for conservation, tourism or educational purposes. The nine examined natural values are all under international protection. They can only be the places to spend our free time actively if we properly take care of them.

Supplementary Information The online version contains supplementary material available at https://doi.org/10.1007/s12371-020-00528-6.

Acknowledgements We thank Barnabás Korbély, Head of BakonyBalaton Geopark Group for the cooperation and the data service. This research was supported by the National Research, Development and Innovation Fund of Hungary, financed under the Thematic Excellence Programme TKP2020-NKA-06 (National Challenges Subprogramme) funding scheme.

Funding Open Access funding provided by Eötvös Loránd University.

Open Access This article is licensed under a Creative Commons Attribution 4.0 International License, which permits use, sharing, adaptation, distribution and reproduction in any medium or format, as long as you give appropriate credit to the original author(s) and the source, provide a link to the Creative Commons licence, and indicate if changes were made. The images or other third party material in this article are included in the article's Creative Commons licence, unless indicated otherwise in a credit line to the material. If material is not included in the article's Creative Commons licence and your intended use is not permitted by statutory regulation or exceeds the permitted use, you will need to obtain permission directly from the copyright holder. To view a copy of this licence, visit http://creativecommons.org/licenses/by/4.0/.

\section{References}

Albert G, Pál M, Gy S (2018) Geological hiking map of the surroundings of Csopak. Schwarcz Maps, Tök

Bakony-Balaton Geopark (2019) Bakony-Balaton Geopark - EGN application http://www.bakony-balaton-geopark.hu/en/home/bakonybalaton-geopark/egn-application. Accessed 11 November 2019.

Božić S, Tomić N (2015) Canyons and gorges as potential geotourism destinations in Serbia: comparative analysis from two perspectives general geotourists' and pure geotourists'. Open Geosci 7:531-546. https://doi.org/10.1515/geo-2015-0040

Brilha J (2002) Geoconservation and protected areas. Environ Convers 29(3):273-276. https://doi.org/10.1017/S0376892902000188

Brilha J (2016) Inventory and quantitative assessment of geosites and geodiversity sites: a review. Geoheritage 8:119-134. https://doi. org/10.1007/s12371-014-0139-3

Bruschi V, Cendrero A (2009) Direct and parametric methods for the assessment of geosites and geomorphosites. In: Reynard E, Coratza P, Regolini-Bissig G (eds) Geomorphosites. Verlag Friedrich Pfeil, Munchen, pp 73-88

Budai T, Császár G, Csillag G, Dudko A, Koloszár L, Majoros GY (1999) Geology of the Balaton Highland. Explanation to the Geological Map of the Balaton Highland 1:50 000. Geological Institute of Hungary, Budapest

Cserny T, Nagy-Bodor E (2000) Limnogeology of Lake Balaton (Hungary). Lake basins through space and time. In: GierlowskiKordesch E H, Kelts K R (eds) AAPG Studies in Geology: Lake Basins Through Space and Time. Am Assoc Pet Geol 46:605-618. https://doi.org/10.1306/St46706

Dövényi Z (2012) Geography of the Carpathian Basin. Akadémiai Kiadó, Budapest

Dowling R (2011) Geotourism's global growth. Geoheritage 3(1):1-13. https://doi.org/10.1007/s12371-010-0024-7

Futó J (2013) Excursions - experience nature next to Lake Balaton and in the Bakony Mountains. Balaton Uplands National Park Directorate, Csopak

Grant C (2010) Towards a typology of visitors to geosites. Second Global Geotourism Conference, Making Unique Landforms Understandable. Mulu, Sarawak, Malaysia

Haas J (ed) (2013) Geology of Hungary. Springer Science \& Business Media

Harangi Sz (2014) Volcanic Heritage of the Carpathian-Pannonian Region in Eastern-Central Europe. Volcanic Tourist Destinations 103-123. https://doi.org/10.1007/978-3-642-16191-9_7

Horváth G, Csüllög G (2011) Geoconservation and geotourism in a new Central European geopark. Landscape Conservation. National Taiwan University, Taipei, pp 31-42

Horváth G, Lóczy D (2015) Geoheritage, geoconservation, geomorphosites in Hungary. In: Lóczy D (ed) Landscapes and Landforms of Hungary. Springer, Cham, pp 281-288

Joyce B (2009) Geomorphosites and volcanism. In: Reynard E, Coratza P, Regolini-Bissig G (eds) Geomorphosites. Verlag Dr. Friedrich Pfeil, München, pp 175-188 
Korbély B (ed.) (2011) An Application for European Geopark Status for the Aspiring Bakony-Balaton Geopark Project. Hungary $52 \mathrm{p}$. http://www.geopark.hu/EGN_Application/BBGp_Application_ web.pdf

Leader European Observatory (1997) Evaluating a territory's touristic potential. Brussels

Migoń P (2018) Qualitative assessment of landforms and landforming processes for geoheritage evaluation - how to define 'significance'. Geophysical Research Abstracts 20:3005, EGU General Assembly

Németh K, Martin U, Sz H (2001) Miocene phreatomagmatic volcanism at Tihany (Pannonian Basin, Hungary). J Volcanol Geotherm Res 111(1-4):111-135. https://doi.org/10.1016/S0377-0273(01)002232

Pál M, Albert G (2018) Identifying outcrops for geological hiking maps. 7th International Conference on Cartography \& GIS: Proceedings 1: 103-108

Pál M, Albert G (2019) Comparison of geotourism assessment models: an experiment in Bakony-Balaton UNESCO Global Geopark. Acta Geoturistica 9(2):1-13. https://doi.org/10.1515/agta-2018-0005

Pál M, Korbély B, Budai T, Albert G (2018) Geotourism assessment in the Csopak area of the Bakony-Balaton UNESCO Global Geopark,
Hungary. Geophysical Research Abstracts 20:685, EGU General Assembly

Pereira P, Pereira D (2010) Methodological guidelines for geomorphosite assessment. Géomorphol: Relief, Processus Environ 16(2):215-222

Reynard E, Fontana G, Kozlik L, Scapozza C (2007) A method for assessing "scientific" and "additional values" of geomorphosites. Geographica Helvetica 62:148-158. https://doi.org/10.5194/gh-62148-2007

Szepesi J, Harangi S, Ésik Z, Novák TJ, Lukács R, Soós I (2017) Volcanic geoheritage and geotourism perspectives in Hungary: a case of an UNESCO world heritage site, Tokaj wine region historic cultural landscape, Hungary. Geoheritage 9(3):329-349

Tomić N, Božić S (2014) A modified geosite assessment model (MGAM) and its application on the Lazar Canyon area (Serbia). Int $\mathbf{J}$ Environ Res 8(4):1041-1052. https://doi.org/10.22059/ijer.2014. 798

Vujičić MD, Vasiljević DA, Marković SB, Hose TA, Lukić T, Hadžić O, Janićević S (2011) Preliminary geosite assessment model (GAM) and its application on Fruška Gora Mountain, potential geotourism destination of Serbia. Acta Geogr Slovenica 51(2):361-377. https:// doi.org/10.3986/AGS51303 